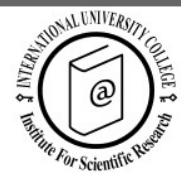

\title{
Dog show participants as tourists: attendance motivation factors
}

\author{
Milosava Matejevic $^{1 *}$, Ksenija Wallrabenstein ${ }^{2}$ and Zoran Ristic ${ }^{3}$
}

Received: 29/03/2013 Accepted: 15/05/2013

\footnotetext{
${ }^{1}$ PhD student, University of Novi Sad, Faculty of Sciences, Department of Geography, Tourism and Hotel Management, Trg Dositeja Obradovica 3, 21000 Novi Sad, Serbia; tel.: +381 63 331055; e-mail: milosava devic@yahoo.com

${ }^{2}$ University of Novi Sad; tel.: +381 60 3101755; e-mail: wksenija@gmail.com

${ }^{3}$ Associate professor, University of Novi Sad, Faculty of Sciences, Department of Geography, Tourism and Hotel Management, Trg Dositeja Obradovica 3, 21000 Novi Sad, Serbia: tel: +381 21485 2786: fax: +381 21 459-696; e-mail: balzakova@yahoo.com

* Corresponding author
}

\begin{abstract}
This study examines the participant motives for attending dog manifestations and events that attract a large number of competitors and attendees in general. Since average dog events participant does not attend every dog event that is organized during one year, but chooses one or more of them, the purpose of the study was to recognize the basic motivational factors in choosing which event to participate in, and to find out in which degree the dog show attendees are interested in tourist activities. In the dog show competitors "Socialization/Networking", "Judges", as well as "Quality and prestige of the event" have been signed out as very important factors of motivation, while the factor "Touristic motives" is of slightly less significance. The results have shown that the Dog Show competitors are one homogenous group that could be touristic interesting if they are offered a proper travel offer.
\end{abstract}

(C) 2014 International University College. All rights reserved

Keywords: dog shows; events; event tourism; participant motivation

Citation: Matejevic, M., K. Wallrabenstein and Z. Ristic (2014) Dog show participants as tourists: attendance motivation factors. European Journal of Tourism Research 7, pp. 16-30

\section{Introduction}

Cynological manifestations or dog competitions, in particular major international competitions, at the present are events that attract large numbers of visitors. About the event as a separate phenomenon has been written by various authors who also gave different classifications of those events, depending on the size, significance, form and content of the event (Jago and Shaw, 1998; Allen et al., 2002; Getz, 2005; Van der Wagen,
2007; Bowdin et al., 2011). However, so far in the present literature has not much been written on the subject of cynological manifestations and especially not on the subject of their tourist aspects. Kennel competitions as events are difficult to classify and categorize into one particular group since they have the characteristic of different types of events. Bearing in mind that one cynological event can have various characteristics festival, trade, sport and recreational, business, 
and tourist; it can satisfy various needs and expectations of diverse visitors. However, defying and classifying cynological events would be a particular theoretical problem that would be the object of a separate study. From the standpoint of the themes of this study should be born in mind that these are the very specific events where dogs are evaluated and classified in exterior or a particular type of work, that follows a series of other uncompetitive activities, like the demonstration of different kinds of dog sports (dog dancing, agility, mondioring) to the presentation and sale of various products for dogs in the consumer exhibition. These competitions may have a local, regional, national or international character, the last two being the most interesting in the context of tourism movements and activities. With this in mind the research carried out for the sake of this study has been conducted among the most important international cynological events in Serbia.

\section{Dog Shows of international character,} especially the European and World Dog Shows gather a significant number of participants and visitors in general, often by tens of thousands. A good example of this is the World Dog Show (WDS) 2008 in Sweden on which the number of entries in the Show and the accompanying contents reached 35.000 (from 53 countries) and the number of competitors and spectators reached $50.000(\mathrm{FCl}, 3 / 08)$. Finland was host to the 13th $\mathrm{FCl}$ Agility World Championships in 2008, which was supported by more than 14.000 spectators $(\mathrm{FCl}, 4 / 08)$. In 2010. the WDS was organized in Denmark, and 19.350 dogs from 54 countries were competing at this event $(\mathrm{FCl}, 3 / 10)$. The WDS and the accompanying dog contests in Paris, in 2010., reached a number of 35.254 registered dogs (Catalogue WDS, 2011).

In the science literature it has already been recognized that the events are an important motive for tourist movements and that planned events can have great significance in increasing competitive advantage of tourist destinations (Getz, 2008). A large number of authors agree that to the offer of a certain tourist destination events play a significant travel, cultural, and social role as well as to contribute to local and the entire regional development (Getz, 1993; Formica \& Uysal, 1998; Felsenstein \& Fleischer, 2003; Gursoy, et al. 2004; O'Sullivan, et al, 2009; Pasanen et al., 2009). According to these authors the events are increasingly viewed as a tourist attraction in itself and as such may affect the growth of the local tourism demand, creating a better image of the community, increasing the level of attractiveness of the tourist destination, the extension of the tourist season. Such events may also increase the tourist traffic beyond the main tourist season. Cynological contests as very specific events are able to attract a large number of different visitors, and as such they may be significant to a specific tourist destination. Those are events that last at least one to four days, depending on their significance, and among the competitors there are a large number of people who travel from their place of residence to participate in these events. Since they usually spend at least one night away from their place of residence, they can be considered for tourists.

The purpose of this study is to suggest who these tourists are, and what motivates this group of people to take a certain journey? Which are the pull factors that separate an event from all others in the eye of the visitors and above all the competitors/participants? We are interested in the answer to the question which are the elements and factors of special significance that raises the need and decisively influence the decision of a particular contestant to apply to a specified event? Event-specific experiences are definitely most important for this type of tourist, but how do they choose and decide to participate in a specified event? This study tends to suggest answers to questions as - in which measure are they really interested in tourist activities during their journey and whether and to what extent may be of interest to tourist workers at a particular tourist destination. The research conducted for the purpose of this study has been an exploratory research from which one cannot draw any general conclusions but further research on this topic would help solve the problem more concretely.

\section{Review of related literature}

Given the lack of literature, theoretical and empirical researches on the cynological 
competitions as events, their attendees and their motivation, in this research authors had to be led by the known research models of tourist motivation. For the same reason, in the literature review authors will focus more on the research of related events and the motives of their visits. Dog events are mentioned in science literature, but in quite other manner. In some researches, dog events, like some hunting tests, and results that dogs made in those tests, were used for estimate genetic parameters for traits (Brenøe et al, 2002; Lindberg et al, 2004).

Bearing in mind the aforementioned diversity of content, programs and characters of the dog show events one can start from the assumption that the motivation of their attendees is in similarity to the motivation of the attendees of trade shows, consumer exhibitions and conventions. Therefore, it is important to rely on the existing literature on these domains in order to successfully accomplish this research.

\section{Tourist motivation}

Although there are other factors that influence the behaviour of tourists, motivation is still the crucial indicator and power that directs the behaviour of tourists in a certain way (Cohen, 1972). For years many authors discuss the motivations of tourists and long been a large number of them agreed that tourist motivation is multifarious, respectively that people take a journey from all kind of reasons (Lundberg, 1971; Crompton, 1979; Mayo \& Jarvis, 1981; Pearce, 1982; Uysal, Gahan \& Martin, 1993). The basis for their research were three known frames, the Maslow's need hierarchy (Maslow, 1970), Iso-Ahola's escape-seeking dichotomy (Iso-Ahola, 1982) and the concept of push-pull factors (Crompton, 1979). Since Crompton's concept of push-pull factors has been widely accepted, and given the fact that beside the intrinsic motivation it also takes into account the external factors as stimulators of motivation, this concept will be seen as most acceptable in this study.

Many authors have accepted the push-pull model (Crompton, 1979; Dann, 1981) that divides touristic needs into two categories: the push factors as the internal motivators (Uysal \& Jurowski, 1994) which form a wanderlust, and pull factors as external motivators (Uysal \& Jurowski, 1994) because they are the result of attractiveness of the destination (Uysal \& Hagan, 1993; Uysal \& Jurowski, 1994) and influence the choice of destination (Crompton, 1979). Push factors precede pull factors (Dann, 1977 ) and the same author later indicates that the destinations pull factors are trying to answer and empower the push factors of tourist motivation, and that tourist during their process of deciding where to travel are looking for equivalents in the pull factors in regard to their push factors of tourist motivation (Dann, 1981). Despite the undoubtedly greater importance of the push factors, the pull factors also play a significant role in the process of tourist motivation. There are undeniable implications of the pull factors to the segmentation of the market as well as the positioning and promotional activities in tourism (Klenosky, 2002). It is from this point of view that the organizers of various events, especially the marketing teams, should have best possible insight into the pull factors of motivation which are of significance to the participant and to continually improve them.

\section{Event attendance motivation}

Many authors have already emphasised the importance of research and understanding of the visitor motivation in certain events (Getz, 1993) for the sake of better planning, promoting and positioning of the events (Scott, 1996; Crompton \& McKay, 1997) as well as attracting as many as possible visitors (Dewar et al, 2001). Special event tourism is very important for international tourism and the economies of host communities (Dwyer et al., 2005; Jackson, 2008). There have been quite many research and discussions in literature on the topic of event tourist motivations, especially on festival and special events visitor motivations (Getz, 1991; Uysal et al., 1993; Mohr et al., 1993; Backman et al., 1995; Scott, 1996; Crompton \& McKay, 1997; Formica and Uysal, 1998; Nicholson \& Pearce, 2001; Lee et al, 2004; Schofield \& Thompson, 2007). Most of these researches are case studies, in which more different factors that influence the festival visitor motivations, have been singled out. The most common of them are: "escape", "socialisation", "cultural exploration" and "novelty"; but they still cannot be shown as unique for all events. 
However, the current literature tends to the generalization and the creation of a unique scale for measuring tourist's event motivation.

Previous research on the topic of visiting exhibitions and fairs has shown that in the decision making process gathering information about the products (Munuera and Ruiz, 1999; Tanner et al., 2001; Smith et al., 2003; Kozak and Kayar, 2009; Whitfield and Webber, 2011), or the market (Lee et al., 2010), has been one of the most significant factors. In the research by Breiter and Milman (2006) as well as in Rittichainuwat's and Mair's research (2012) networking has been emphasized as the most common reason for visiting exhibitions. This factor is also given in other studies, although not as the first and most important factor of motivation, and within that researchers most often include the possibility of exchanging ideas with others and getting to know the experts. Other factors of significance that previous mentioned research have revealed are "quality of exhibits" and "destination image", "job connections", "purchasing", "reputation of exhibition", "attending seminars and special events" and "exhibition specifics".

Conducted researches concerning convention attendance have shown that the most significant factors that influence the attendance are mostly "networking" and "education/business opportunities", while other important factors are concerning the conference program, as well as the location and destination (Oppermann and Chon, 1997; Rittichainuwat et al., 2001; Severt et al., 2007; Yoo and Chon, 2008; Mair and Thompson, 2009; Tanford et al., 2012). Severt et al. (2007) add "products and deals" as factor of significance, while Tanford et al. (2012) add "external activities" and "cost". Yoo and Chon (2008) indicate the appearance of the factor "safety and health situation" as a result of terrorism and health crises, which have been confirmed in the research other authors (Mair and Thompson, 2009).

\section{Research questions}

As participants in dog events in country and abroad, opinion of authors was that well organised and planned event could be interesting in a form of tourism. Bearing in mind the similarities but also the significant differences between the exhibitions (consumer and trade show) and the cynological events, the authors preference is that this research should be to some extent similar to previous researches, therefore thus formulated its objectives and research questions. At the same time, the specificity and "obscurity" of cynological events and their attendees the authors have tried to shape in through specific exploratory questions:

$\checkmark \quad$ The main task of this study is to extract the factors of competitors motivation at kennel events. Which are the factors and the strength of their effects on the competitors to choose to be a participant of a certain cynological event?

$\checkmark \quad$ A particular and specific task of this study is to identify and describe the competitor in a cynological event as well as to explore if this group of "tourists" is homogenous, or whether there are differences between them. In case the group is not homogenous, it is necessary to identify and segment this market of tourist demand too.

All information about the actual competitors as tourist demand and their motives, which this study is trying to contribute, could be useful at a great extent to the organisers of cynological events, in purpose of improving the offer or organisation. This could also be useful to the tourist workers in the place of the events, in order to improve the tourist offer and the effects of tourist spending.

\section{Methodology}

In this study different methods of data collection and analysis of results have been used. Before the construction of the questionnaire and conducting scientific research, an interview with the dog show competitors and judges has been used as one of the methods of insight into the basic aspects of their motivation. Authors used available literature that is not being very rich. Previous personal experiences in the field of tourist travel connected to dog show events, have also been used as well as informal contacts with people from this milieu. Based on the collected data a questionnaire was constructed and distributed to competitors at the International exhibitions of dogs of all breeds in Belgrade (1230 dog entries). This research was 
conducted in November in 2012. At the end of research, there were 152 questionnaires, but a certain number of them were filled incorrect. Thus, the number of properly and fully completed questionnaires was 109. This sample can represent population of dog events participants, considering sample size of $8,9 \%$ of the total population and small variability of studied phenomena. Thus, it is suitable for generalisation.

In the analysis of results of this study, methods of descriptive statistics were primarily used. By these methods, a description of the sample was implemented, i.e., a description of competitors in cynological events in Serbia and their behaviour. Further the EFA (Exploratory factor analysis) method was used, which served to extract the factors of motivation in the cynological event attendees. In the end methods of parametric statistics (t-test, ANOVA) were used to determine the possible existence of statistically significant differences between different groups of visitors, compared to disparate factors of motivation that is to identify any subset of data that would indicate the existence of different clusters. Also, the Pearson correlation has been used.

\section{Questionnaire design}

For the purposes of this study a questionnaire was formed after discussions with participants and organisers of dog events (organisers, judges, dog owners, dog handlers, etc.). From their experience, authors concluded that external motives are more important in choosing what dog event to participate in.

The questionnaire consisted of two parts. In the first part, the respondents declared on several of their socio-demographic characteristics (gender, age, education, economic status), as well as on their behaviour before and during the cynological events. They were asked if they have their own kennel, how many dogs they take to the shows, how often they attend at cynological events at home and abroad, with whom they pass them, in which way they gather information, etc. The answers to these questions will help to gain a better insight of who the dog event attendees really are.
The second part of the questionnaire consisted of a scale of 41 questions, related to various possible motives and needs of the dog show participants, and they could present the possible pull factors of cynological events. On a five-point Likert-type scale ( $1=$ not at all important, 5=very important) respondents spoke about the effect of each of these motives for them personally. Data from these scales were then entered into SPSS 11.5, and factor analysis was performed with the aim of separating a factor of higher order.

\section{General profile of respondents}

In a sample of 109 respondents, men are dominating $(\mathrm{N}=80)$ and represent $73,4 \%$ of respondents. The average age of the respondents is 35.68 years. The educational structure is uniform, therefore respondents with secondary school are $49.5 \%$ and those with college and university are $50.5 \%$. Financial status of the respondents marked mainly those with average incomes in Serbia $(48.6 \%)$ while those with below-average income made up $33 \%$ of the sample and least are those with above-average income $18.3 \%$.

The majority of respondents or competitors at cynological events possesses a kennel $(\mathrm{N}=56)$ and they make up $51.4 \%$ of the sample. At the same time, most of the respondents attend cynological events even when they do not compete with their own dog (even $67.9 \%$ ). When they take their own dog to the competition most of them (49.5\%) usually take only one dog, while $37.6 \%$ of the respondents take two dogs to the competition. Least is those who take more than two dogs at once to a single competition, only $12.8 \%$ of the respondents.

In relation to the preferences, the respondents pleaded to prefer dog shows of all breeds (58\% of them), while slightly fewer prefers specialized dog shows (30.3\%) and least of the respondents prefer to attend working contests (only 11\%).

In relation to the frequency of participation in cynological events in Serbia, the respondents have declared themselves in the following way: about one-third of the respondents (33.9\%) attend in these events rarely (once a month or 
more rarely). At the same time $32.1 \%$ of the respondents participate in these events in average twice a month, until remained $33.9 \%$ of the respondents declare to participate such events even more often, in average more often than twice a month.

As for the participations at dog shows abroad, here the results are slightly different. Even $45.9 \%$ of the respondents $(\mathrm{N}=50)$ declared not to participate in such events or to participate very rarely (in average less than once a year). Most of them who do not attend in dog events abroad as primary cause point out "lack of funds" (38.5\%), "lack of free time" $(14.8 \%)$, and "distance from the place of event" (13.8\%). A strong competition or poor quality of the dog, have not proved to be a significant cause of avoiding cynological events abroad.

Of those respondents who attend events abroad $(\mathrm{N}=59), 43$ of them $(39.4 \%)$ attends such events in average 1-3 times a year, while only $14.7 \%$ of the respondents $(\mathrm{N}=16)$ travel abroad to attend cynological events more than 4 times a year in average.

The respondents inform themselves about the cynological events mainly in the Internet (even $89 \%$ ), while $38.5 \%$ of them use specialised magazines in addition, as well as friend and acquaintances $(32.1 \%)$. Flyers and leaflets are a useful source of information for only $10.1 \%$ of respondents, while the TV is nearly insignificant as source of information and is used by only $2.8 \%$ of the respondents.

A large majority of the respondents attends the events socially, so $49 \%$ respondents attends mostly together with friends, while $43.1 \%$ of them does it in the company of their families. Least of them mostly attend by themselves, only $7.3 \%$.

When attending dog events, there is only a small number of those, for whom the tourist aspect of the visit is of great importance or entirely irrelevant. So only $12.8 \%$ respondents declared to conduct regularly sightseeing tours of every city in which the event is held, and only $14.8 \%$ of respondents declared to never visit the tourist place where the event is held By far the most respondents $72.5 \%$ take into account the touristic dimension of these events and from time to time make sightseeing tours of tourist attractions in the places of the events.

Through the description of the sample and the answers to some basic questions on socio demographic characteristics and behaviour of competitors, we profiled the average Serbian competitor in cynological events: Male, in his thirties, with solid education but of average or poor financial status. He likes to visit dog shows in his country, especially all-breed shows, even when he does not take his own dog to the competition. He attends with his friends or family and from time to time he makes sightseeing tours in the place of the event. Therefore those are dog and cynology lovers who developed their hobby into a business activity as source of additional profit. At the same time, because of lack of funding or free time, rarely attends dog events abroad but stays actively informed about everything on the Internet or by other competitors.

\section{Results}

Measurement of motivation for attendance

Before starting the analysis of the factors of motivation, the results of motivators separately will be analysed. Table 1 shows the strongest and weakest motivators (from a list of 41 motivators). The strongest motivators stood out those in relation to quality of dog evaluation and judges. So the competitors indicate the motivator "fairness in grading" as the most important motive for registration on a competition. At the same time, as second strongest motivator, the competitors indicate "experience of a certain judge", while "quality of the list of judges" and "reputation of a certain judge" are placed as $3^{\text {rd }}$ and $5^{\text {th }}$ motivator by strength. These results suggest that the most important principle for the competitors is the principle of justice, respectively their perception of the quality of the evaluation, which is reflected through the reputation and experience of the judge, or the competitors' beliefs that judges will judge fairly and efficiently. As the competitors do not compete with each other but they are being represented by their dogs as their "products' or the "products of their invested labour, knowledge and financial resources", they expect the competition to be fair and their investment to be fairly evaluated. 
In order to better understand the significance of these motivators we must bear in mind the profile of the participants and competitors in the dog events, especially in major international competitions, since they are not just ordinary dog lovers, but also professional dog breeders to whom cynology is not only their hobby but more importantly, their business.

The principle of justice, in particular in the competitions is an ethical principle which is dominant in all societies, thus, one might expect that this principle of fair trial is an equally important motivator for competitors in all states and therefore could be generalized. This would mean that the organisers of cynological competitions, if they want to attract as many competitors as possible (and thus the audience too) have to offer, above all, fair and experienced judges with extraordinary reputation.

Motivators that have proven to be very significant and do not fall under the principle of fairness are "opportunity to meet owners of quality dogs for the purpose of future dog reproduction" as well as "socialising with friends" which could partly be interpreted as social factors and in the other part as "networking", while the motivator "safety and security of dogs and attendees in place/state of event" represents the basic need for security which is to a significant degree present in all areas of life, and so in tourism. This safety factor has already been identified in previous studies of event attendance (Yoo and Chon, 2008; Mair and Thompson, 2009).

"The possibility of week competitors in the competition" proved to be the least important motivator $(M=2,12)$ which speaks about the competitive spirit of respondents and their need to compete in a strong competition, probably to make their possible awards more worth. Events with a large number of dogs represent prestigious events and thus the obtained titles have the same character. Such events are not only a challenge for the competitive cynologists, but also a possibility to make new acquaintances in the world of cynology which could be of cynological business as well as social importance.
The factor of "profitability of event participation" appeared rather insignificant factor $(M=2.39)$ What is particularly interesting is that the motivators, four of them, associated with the tourist attractions and events in the place of the cynological event or nearby, are on the same bottom of the list of motivator significance. They are very low evaluated by the influence they have to the contestants (from $M=2.61$ to $M=2.75$ ). Practically, in the choice of the event in which to participate in, the contestants are almost in no way determinate by tourist motives, or pull factors regarding the tourist attractions of the destination. However, the majority of respondents in the first part of the questionnaire answered that they sometimes visit the tourist places where the events are held. Therefore, tourist attractions in the place of event or nearby are not representing a primary or significant pull factor which influences the contestants, but if they are on the destination or venue of the event offered some tourist attraction some or the majority of them would visit it and in this way take part in the typical tourist movements.

The factor analysis was conducted on the 41 items of contestant's motivation factors in the choice of the cynological event in which to participate. Four factors were singled out in this way with their characteristic root higher then 2 (Table 2) while at the same time were singled out eleven factors with their characteristic root higher than 1. To facilitate the analysis, generalization and comparison with the previously obtained factors in the previous researches, the authors have chosen to single out those with the root higher than 2.The factors were rotated by the Varimax rotation with Kaiser's normalisation. These four factors explain $48.01 \%$ of the total variance.

The internal consistency of the instrument measurements (with 41 items) was confirmed by the resulting Crombach's alpha $(a=0.913)$ and the adequacy of sampling declares the obtained KMO (Kaiser-Meyer-Olkin measure of sampling) of 0.827 .

The first extracted factor of higher order refers to 11 items which tell about the organisation, quality and prestige of the manifestation, ad about what is the merit of the organisers of the 
Table 1. The most significant and most insignificant motivators for the attendees in cynological events

\begin{tabular}{|c|c|c|}
\hline & Mean & $\begin{array}{c}\text { Std. } \\
\text { Deviation }\end{array}$ \\
\hline Fairness in grading & 4.73 & 0.603 \\
\hline Experience of a certain judge & 4.52 & 0.765 \\
\hline Quality of the judge list & 4.37 & 0.969 \\
\hline Opportunity to meet owners of quality dogs for the sake of future dog's reproduction & 4.37 & 0.801 \\
\hline Reputation of a certain judge & 4.35 & 0.854 \\
\hline Socializing with friends & 4.28 & 0.806 \\
\hline Safety and security of dogs and attendees in the place of the event & 4.28 & 0.932 \\
\hline The ability to acquire new knowledge and experiences in breeding of a certain breed & 4.23 & 0.959 \\
\hline The ability to create a good image and famous name in the world of dog breeders & 4.21 & 0.914 \\
\hline Functionality of the place of the event & 4.21 & 1.001 \\
\hline Significance of the obtained rating on a particular event & 4.20 & 0.960 \\
\hline Making new cynological acquaintances & 4.14 & 0.822 \\
\hline Previous positive experiences with a certain event & 4.14 & 0.897 \\
\hline Possibility of good care and preparation of the dogs for the show & 4.13 & 0.914 \\
\hline Possibility of spending quality time with friends and family & 4.12 & 1.025 \\
\hline Importance of won titles in a particular event & 4.12 & 0.868 \\
\hline Prestige of grades/titles which are given & 4.07 & 0.879 \\
\hline Professionalism in organizing of a certain cynological event & 4.06 & 0.951 \\
\hline Getting experience in dog showing & 4.04 & 0.981 \\
\hline Good reputation of a certain cynological event & 4.03 & 0.855 \\
\hline Socializing with lovers of a certain breed & 4.00 & 0.943 \\
\hline Hospitality of the organizers & 3.96 & 1.027 \\
\hline Accuracy of the time in the organization of the event & 3.88 & 1.120 \\
\hline Bad reputation of a certain event & 3.83 & 1.198 \\
\hline Accessibility of facilities of the event & 3.74 & 1.182 \\
\hline Financial costs of the journey, commodity and show & 3.71 & 1.021 \\
\hline Amiability of the judge & 3.66 & 1.047 \\
\hline Possibility of strong competition in the contest & 3.37 & 1.259 \\
\hline Cordiality of the organizing team members & 3.35 & 1.174 \\
\hline Spaciousness of the place of the event & 3.27 & 1.230 \\
\hline Quality of the commodity in the place of the event & 3.27 & 1.127 \\
\hline Distance of the city or place of the event & 3.13 & 1.187 \\
\hline Cynological knowledge and experience of the other contestants & 3.13 & 1.187 \\
\hline Expected number of applied dogs(contestants) & 2.83 & 1.304 \\
\hline Attractiveness of city/place of event & 2.81 & 1.142 \\
\hline Distance from certain tourist attractions & 2.75 & 1.256 \\
\hline Distance from certain natural attractions & 2.69 & 1.136 \\
\hline Simultaneous performance of other events & 2.63 & 1.207 \\
\hline Vicinity of certain cultural and historical heritage & 2.61 & 1.240 \\
\hline Profitability of event participation & 2.39 & 1.147 \\
\hline Possibility of poor competition in contest & 2.12 & 1.103 \\
\hline Valid $N=109$ & & \\
\hline
\end{tabular}

\section{Factor analysis of the motivating factors for attendance}

event. This factor is named as "Quality and prestige of the event". The second extracted factor includes 4 items that relate directly to social contacts and networking. The fifth item, which was firstly classified in this factor, stands in negative correlation and relates to the distance of the city or place of the event, thus it has been dropped from the factor. The third 
Table 2. Factor analysis of the motivating factors for attendance

\begin{tabular}{|c|c|c|c|}
\hline Factors & Saturation & $\begin{array}{l}\text { Explained } \\
\text { variance }\end{array}$ & $\alpha$ \\
\hline Factor 1: Quality and prestige of event & & 25.412 & 0.864 \\
\hline Fairness in grading & 0.733 & & \\
\hline Significance of obtained titles in a particular event & 0.728 & & \\
\hline Significance of obtained rating in a particular event & 0.673 & & \\
\hline Prestige of the titles and ratings that are being given & 0.651 & & \\
\hline Accuracy of the time in the organization of the event & 0.641 & & \\
\hline Previous positive experience with a certain event & 0.628 & & \\
\hline Safety and security of dogs and visitors in the place of event & 0.616 & & \\
\hline Quality of the commodity in the place of the event & 0.554 & & \\
\hline Bad reputation of a certain cynological event & 0.534 & & \\
\hline Quality of the list of judges & 0.518 & & \\
\hline Spaciousness of the place of the event & 0.517 & & \\
\hline Factor 2: Socialisation / Networking & & 9.832 & 0.787 \\
\hline $\begin{array}{l}\text { Opportunity to meet owners of quality dogs for the sake of future dog } \\
\text { reproduction }\end{array}$ & 0.712 & & \\
\hline Making new cynological acquaintances & 0.676 & & \\
\hline Socialising with friends & 0.593 & & \\
\hline $\begin{array}{l}\text { Opportunity to acquire new knowledge and experience in breeding of a } \\
\text { certain breed of dogs }\end{array}$ & 0.552 & & \\
\hline Factor 3: Tourist motives & & 6.478 & 0.848 \\
\hline Vicinity of certain cultural and historical heritage & 0.823 & & \\
\hline Distance from certain natural attractions & 0.800 & & \\
\hline Distance from certain tourist attractions & 0.760 & & \\
\hline Attractiveness of city and place of event & 0.747 & & \\
\hline Possibility of poor competition in contest & 0.560 & & \\
\hline Factor 4: Judges & & 6.297 & 0.712 \\
\hline Reputation of a certain judge & 0.682 & & \\
\hline Experience of a certain judge & 0.641 & & \\
\hline
\end{tabular}

factor is named "Tourist motives" for it includes all items that are related to the tourist motivation of the participants. The fourth extracted factor we called "Judges", respectively two of three items relate to the reputation and experience of a certain judge, which should cause a quality trial during the competition. The third negatively correlated item refers to the financial costs during the attendance in the event, thus it has been dropped. This refinement provided more significant and acceptable Crombach's alpha. 
Table 3. Indicator review of the descriptive statistic for all four factors

\begin{tabular}{lcr}
\cline { 2 - 3 } & Mean & Std. Deviation \\
\hline F 1: Quality and prestige of event & 4.0150 & 0.63895 \\
F 2: Socialisation / Networking & 4.2546 & 0.61046 \\
F 3: Tourist motives & 2.5945 & 0.92914 \\
F 4: Judges & 4.4358 & 0.70086 \\
\hline
\end{tabular}

Valid $\mathrm{N}=109$

Table 4. F-test (ANOVA): Do you go in sightseeing the city where the event took place? Factor 3

\begin{tabular}{llccccc}
\cline { 3 - 6 } & & $\begin{array}{c}\text { Sum of } \\
\text { Squares }\end{array}$ & df & $\begin{array}{c}\text { Mean } \\
\text { Square }\end{array}$ & F & Sig. \\
\hline Factor 1 & Between Groups & 0.495 & 2 & 0.248 & 0.602 & 0.549 \\
& Within Groups & 43.596 & 106 & 0.411 & & \\
Factor 2 & Total & 44.091 & 108 & & & \\
& Between Groups & 1.266 & 2 & 0.633 & 1.722 & 0.184 \\
& Within Groups & 38.981 & 106 & 0.368 & & \\
Factor 3 & Total & 40.248 & 108 & & & \\
& Between Groups & 23.399 & 2 & 11.700 & 17.758 & 0.000 \\
& Within Groups & 69.837 & 106 & 0.659 & & \\
Factor 4 & Total & 93.237 & 108 & & & \\
& Between Groups & 0.074 & 2 & 0.037 & 0.074 & 0.928 \\
& Within Groups & 52.976 & 106 & 0.500 & & \\
& Total & 53.050 & 108 & & & \\
\hline
\end{tabular}

As it can be seen from the Table 3, three of four extracted factors by significance are on average very important for the participants. As factor with highest average score $(M=4.43)$ appears the Factor 4 (Judges), while Factor 2 (Socialisation / Networking) is less important, and also the Factor 1 (Quality and prestige of the event) is very important. Of significantly lower power is the Factor 3 (Tourist motives). These findings reaffirm the earlier reported finding of significantly lower importance of tourist attractions and attractiveness of the venue of the event, as compared to other motives or factors.

\section{Testing the significance of differences}

In order to establish statistically significant differences in the arithmetic middles of certain factors, we started testing the statistical significance of the differences (by t-test and Ftest) between different groups of respondents, for every extracted factor. By a large number of intersections of variables of extracted factors and different socio-demographic characteristics of competitors, we got very few differences between the groups in relation to the factors of motivation. These test results show that the participants, or contestants, at events are mostly a homogeneous group, which may not be the case if we observe the visitors in general, and not only the competitors.

Applying the t-test, we determined that there were no statistically significant differences between subjects with respect to all four factors, as there are no statistically significant differences between the two groups of respondents with different levels of education (secondary, college/high) or between those who own or do not own a kennel. In the F-test (ANOVA), we found that there are no differences in the strength of the interaction of four factors of motivation or the respondents of different incomes, as well as to those 
Table 5. Multiple comparisons; LSD

\begin{tabular}{|c|c|c|c|c|c|c|c|}
\hline \multirow[t]{2}{*}{$\begin{array}{l}\text { Dependent } \\
\text { Variable }\end{array}$} & \multirow[t]{2}{*}{ (I) sightseeing } & \multirow[t]{2}{*}{$\begin{array}{l}(\mathrm{J}) \\
\text { sightseeing }\end{array}$} & \multirow[t]{2}{*}{$\begin{array}{c}\text { Mean } \\
\text { Difference } \\
(\mathrm{I}-\mathrm{J})\end{array}$} & \multirow[t]{2}{*}{ Std. Error } & \multirow[t]{2}{*}{ Sig. } & \multicolumn{2}{|c|}{$\begin{array}{l}95 \% \text { Confidence } \\
\text { Interval }\end{array}$} \\
\hline & & & & & & $\begin{array}{l}\text { Lower } \\
\text { Bound }\end{array}$ & $\begin{array}{l}\text { Upper } \\
\text { Bound }\end{array}$ \\
\hline \multirow[t]{6}{*}{ FACTOR 1} & \multirow[t]{2}{*}{ yes } & \multirow{2}{*}{$\begin{array}{l}\text { no } \\
\text { sometimes }\end{array}$} & -0.1315 & 0.23470 & 0.576 & -0.5968 & 0.3338 \\
\hline & & & 0.0597 & 0.18597 & 0.749 & -0.3090 & 0.4284 \\
\hline & \multirow[t]{2}{*}{ no } & yes & 0.1315 & 0.23470 & 0.576 & -0.3338 & 0.5968 \\
\hline & & sometimes & 0.1912 & 0.17582 & 0.279 & -0.1574 & 0.5397 \\
\hline & \multirow[t]{2}{*}{ sometimes } & yes & -0.0597 & 0.18597 & 0.749 & -0.4284 & 0.3090 \\
\hline & & no & -0.1912 & 0.17582 & 0.279 & -0.5397 & 0.1574 \\
\hline \multirow[t]{5}{*}{ FACTOR 2} & \multirow[t]{2}{*}{ yes } & no & 0.4063 & 0.22193 & 0.070 & -0.0337 & 0.8462 \\
\hline & & sometimes & 0.2563 & 0.17585 & 0.148 & -0.0923 & 0.6050 \\
\hline & no & $\begin{array}{l}\text { yes } \\
\text { sometimes }\end{array}$ & $\begin{array}{l}-0.4063 \\
-0.1499\end{array}$ & $\begin{array}{l}0.22193 \\
0.16625\end{array}$ & $\begin{array}{l}0.070 \\
0.369\end{array}$ & $\begin{array}{l}-0.8462 \\
-0.4795\end{array}$ & $\begin{array}{l}0.0337 \\
0.1797\end{array}$ \\
\hline & \multirow[t]{2}{*}{ sometimes } & yes & -0.2563 & 0.17585 & 0.148 & -0.6050 & 0.0923 \\
\hline & & no & 0.1499 & 0.16625 & 0.369 & -0.1797 & 0.4795 \\
\hline \multirow[t]{5}{*}{ FACTOR 3} & \multirow[t]{2}{*}{ yes } & no & $1.6786\left(^{*}\right)$ & 0.29705 & 0.000 & 1.0896 & 2.2675 \\
\hline & & sometimes & $1.2248\left(^{*}\right)$ & 0.23537 & 0.000 & 0.7581 & 1.6914 \\
\hline & \multirow[t]{2}{*}{ no } & yes & $-1.6786\left(^{*}\right)$ & 0.29705 & 0.000 & -2.2675 & -1.0896 \\
\hline & & sometimes & $-0.4538\left(^{*}\right)$ & 0.22253 & 0.044 & -0.8950 & -0.0126 \\
\hline & sometimes & yes & $-1.2248\left(^{*}\right)$ & 0.23537 & 0.000 & -1.6914 & -0.7581 \\
\hline \multirow{6}{*}{ FACTOR 4} & \multirow{2}{*}{ yes } & $\begin{array}{l}\text { no } \\
\text { no }\end{array}$ & $\begin{array}{r}0.4538\left({ }^{*}\right) \\
0.0536\end{array}$ & $\begin{array}{l}0.22253 \\
0.25872\end{array}$ & $\begin{array}{l}0.044 \\
0.836\end{array}$ & $\begin{array}{r}0.0126 \\
-0.4594\end{array}$ & $\begin{array}{l}0.8950 \\
0.5665\end{array}$ \\
\hline & & sometimes & -0.0208 & 0.20500 & 0.919 & -0.4272 & 0.3856 \\
\hline & \multirow[t]{2}{*}{ no } & yes & -0.0536 & 0.25872 & 0.836 & -0.5665 & 0.4594 \\
\hline & & sometimes & -0.0744 & 0.19381 & 0.702 & -0.4586 & 0.3099 \\
\hline & \multirow[t]{2}{*}{ sometimes } & yes & 0.0208 & 0.20500 & 0.919 & -0.3856 & 0.4272 \\
\hline & & no & 0.0744 & 0.19381 & 0.702 & -0.3099 & 0.4586 \\
\hline
\end{tabular}

Note: * Significant at the 0.05 level

Table 6. Correlations between factors and age

\begin{tabular}{llcccc} 
& & Factor 1 & Factor 2 & Factor 3 & Factor 4 \\
\hline Age & Pearson & -0.036 & -0.070 & $0.226^{*}$ & $0.189^{*}$ \\
& Correlation & 0.709 & 0.472 & 0.018 & 0.048 \\
& Sig. (2-tailed) & & & & \\
& $\mathrm{N}=109$ & & &
\end{tabular}

* Correlation is significant at the 0.05 level (2-tailed).

respondents who show different numbers of dogs, as well as those who attend the events in the company of their friends and families or by themselves.

We found significant statistical differences by applying the F-test (ANOVA- one-way analysis of variance), with Post Hoc LSD test in the
Factor 3 (Tourist motives), and between three groups of the respondents related to sightseeing a town/city where a dog event takes place (always, sometimes or never). The results (Table 4; $\mathrm{F}=17.758$; $\mathrm{df}=2$; Sig. $=0.000$ ) indicate that there are 3 subsets of data (Table 5 ), and, as expected, those who always go in sightseeing, in significantly greater extent 
valued Factor 3 as important to them $(M=3.73)$ than the rest of respondents (sometimes or never do sightseeing). Second subset of data consists of those who sometimes visit the place of the event (Factor 3; $M=2.50$ ) and they are significantly different with respect to Factor 3 than the group who never visits the place $(\mathrm{M}=2.05)$.

The results showed that dog events competitors are fairly homogeneous population, which shows a great similarity in the evaluation of motives, that is, the pull factors of the event that they will participate in. However, in relation to tourist motivation and the importance of pull factors of the destination, there is a significant difference between them. Thus, it can be assumed that competitors who value more tourist attraction as pull factors of destinations as well as the dog event, in decision-making process for participating, they will take into account the tourist (pull) factor, especially in a situation when the event organizers contribute the promotion and advertising of the destination itself.

Interesting findings were obtained by applying the Pearson correlation between the age of the respondents and the Factor 3 - Tourist motives (Table 6). Here we received a positive correlation $(r=0.226)$ between the age and the power of the tourist motives, which means that the older respondents are being more drawn by tourist motives. This could be explained by the fact that the contestants with the growing age lose their competitive spirit that has followed them for a long time and are able to find their attendance motivation in a cynological event also in the tourist attractions of the place of the event. Besides, there is also a correlation, although not very strong, between age and Factor 4 (Judges). For contestants with the growing age, and possibly with growing experience, respectable judges are of greater importance.

\section{Discussion and conclusion}

Dog events, as very specific events, attract a large number of visitors; most of them, of course, are the competitors without whom these events could not take place. Therefore, the organisers of cynological events are obligated to above all attract as much contestants as possible, which entails strong competition, which further entails a larger number of business organisations as exhibitors within the consumer exhibitions which are often the additional segment of large dog shows. All this is a good basis for the attraction of other visitors who are not competitive but intend to use their free time in a quality and fun manner. The results of this study can be used by the organizers of these events, as well as guidelines for the development of the organisation and the achievement of certain quality competitions, because high quality dog shows can bring, among others, important economic benefits for both the organisers and the local community.

The results shown in this study indicate that the basic pull factors of cynological events which impact the competitors are The Judges, respectively fairness, expertise, experience, and reputation of the judges. Organisers who want to attract as much as possible more participants /contestants should offer, above all, the best possible list of judges, and beside the safety and security of the visitors and dogs as well as a strong competition in the contest, they would get the opportunity for useful and pleasant social contacts to which contestants also stream. Tourist attractions, in the place of the event, could be significantly higher valorised but beside a good and adequately offer on the spot. As independent pull factor tourist attractions are not of great importance to the competitors at cynological events when they choose in which event to participate in.

Given the previous research that emphasises "networking" as most common reason for visiting exhibitions, as well as conferences, it can be concluded that social motives and networking are being extracted in this study too and recognized as significant factor of cynological events which besides their specificities have much in common with these events. The Factor "Socialisation/Networking" has a wider meaning in this study for it does not only represent the possibility of exchanging ideas with others and meeting experts as said in the mentioned researches but also all the other social contacts. And if we bear in mind that cynological events are also of competitive character, no wonder the judges and their 
quality are extracted as independent factor, also with a significant importance to the participant's motivation.

The very quality of the event is, as expected, a very significant factor of motivation for the visitors and exhibitors at any event, in particular those of fair and competitive type and can be found in almost any previous research as significant factor of fair events. The factor "quality and prestige of the event" can in a certain measure be connected to the factors "quality of exhibitors" and "reputation of the show" which have been identified by Breiter and Milman (2006) in their researches on exhibition visits, but can also be connected to the "program quality" and similar factors of significance which are in direct connection to the conference program, and are being highlighted in the research on conference attendance.

It can be concluded that the touristic motives, or pull factors, of tourist attraction of the event destination are extracted factors which act in the lowest intensity on the competitors in their decision-making process. In contrast to majority of Serbian tourists, this is very different result, since the tourist attraction is one of main motives for choosing summer holiday destination, beside price and accommodation (Wallrabenstein, 2009). Nevertheless, such result could derive from the fact that the organizers do not inform the competitors about the tourist attractiveness of the place of event, neither they advertise them, so there is nothing to motivate the competitors in a touristic sense since they do not have information about the very destination of the event. At the same time, the competitors who arrive to a certain destination, in a very low percent $(14,8 \%)$ show complete touristic ignorance, while the rest shows more or less interest for the tourist attractions of the destination. Therefore should the organizers of Dog Shows and even more the tourist workers in the places of such events focus on this, major segment of competitors and offer them as many different attractive tourist programs on the spot of the event. In this way they would accomplish as higher tourist valorisation from the competitors, respectively the "tourists", to whom the tourist motive is not the primary motive for travel.

\section{References}

Allen, J., O'Toole, W., McDonnell, I., \& Harris, R. (2002) Festivals and special event management (3rd ed.). John Wiley \& Sons Ltd: Australia

Backman, K.F., Backman, S. J., Uysal, M., \& Sunshine K. M. (1995). Event tourism: An examination of motivations and activities. Festival Management and Event Tourism 3, 15-24.

Bowdin, G., Allen, J., O'Toole, W., Harris, R., \& McDonnell, I. (2011). Events management (3rd edition). Elsevier Ltd: UK.

Breiter, D., \& Milman, A. (2006). Attendees' needs and service priorities in a large convention center: application of the importance-performance theory. Tourism Management, 27, 1364-1370.

Brenøe, U. T., Larsgard A.G., Johannessen, KR. \& Uldal, S.H. (2002). Estimates of genetic parameters for hunting performance traits in three breeds of gun hunting dogs in Norway. Applied Animal Behaviour Science 77, 209215.

Cohen E. (1972). Toward a sociology of international tourism. Social Research 39(1), 164-182.

Crompton, J. (1979) Motivation for pleasure travel. Annals of Tourism Research 4 408-424.

Crompton, J.L., \& McKay, S.L. (1997). Motives of visitors attending festival events. Annals of Tourism Research 24 (2) 425-439.

Dann, G. (1977). Anomie, ego-enhancement and tourism. Annals of Tourism Research, 4(4), 184-194.

Dann, G. (1981). Tourist motivation: an appraisal. Annals of Tourism Research, 8(2), 187-219.

Dewar, K., Meyer, D., \& Wen, M. (2001). Harbin, lanterns of ice, sculptures of snow. Tourism Management 22(5), 523-532.

Dwyer, L, Forsyth, P., \& Spurr, R. (2005). Estimating the impacts of special events on an economy. Journal of Travel Research 43(4), 351-359.

FCl World Dog Show Stockholm (2008). Svenska Kennelklubben. Exibition Catalogue. 
Matejevic, M., K. Wallrabenstein and Z. Ristic (2014) / European Journal of Tourism Research 7, pp. 16-30

FCl World Dog Show Paris (2011) Catalogue officiel.

Fédération Cynologique Internationale (FCl) Magazine, Issue 3,4/2008 \& 3/2010, Stratego Werbe- und Verlagsgesellschaft Marz, Mühlenweg

Felsenstein, D., \& Fleischer, A. (2003). Local festivals and tourism promotion: the role of public assistance and visitor expenditure. Journal of Travel Research, 41(4), 385-392.

Formica, S., \& Uysal M. (1998). Market segmentation of an international cultural-historical event in Italy. Journal of Travel Research 36(4), 16-24.

Getz, D. (1991). Festivals, special events, and tourism. New York: Van Nostrand Reinhold.

Getz, D. (1993). Festivals and special events. In M. Khan, M. Olsen \& T. Var (Eds.). Encyclopedia of hospitality and tourism (pp.789-810), New York: Van Nostrand Reinhold

Getz, D. (2008). Event tourism: Definition, evolution, and research. Tourism Management 29(3), 403-428.

Gursoy, D., Kim, K., \& Uysal, M. (2004). Perceived impacts of festivals and special events by organizers: an extension and validation. Tourism Management, 25(2), 171-181.

Iso-Ahola, S.E. (1982). Toward a social psychological theory of tourism motivation. Annals of Tourism Research 9, 256-262.

Jackson, L. (2008). Residents' perceptions of the impacts of special event tourism, Journal of Place Management and Development 1(3), 240-255.

Jago, L.K., \& Shaw, R.N. (1998) Special events: A conceptual and differential framework. Festival Management and Event Tourism 5(1/2): 21-32.

Klenosky, D. (2002). The "pull" of tourism destinations: A means-end investigation. Journal of Travel Research 40(4), 396-403.

Kozak, N., \& Kayar, C.H. (2009). Visitors' objectives for trade exhibition attendance: A case study on the East Mediterranean International Tourism and Travel Exhibition (EMITT). Event Management 12 (3-4), 133-141.
Lee, C., Lee, Y., \& Wicks, B.E. (2004). Segmentation of festival motivation by nationality and satisfaction. Tourism Management 25(1), 61-70.

Lee, M.J., Yeung, S., \& Dewald, B. (2010). An exploratory study examining the determinants of attendance motivations as perceived by attendees at Hong Kong exhibitions. Journal of Convention and Event Tourism 11, 195-208.

Lindberg, S., Strandberg, E., \& Swenson, L. (2004). Genetic analysis of hunting behaviour in Swedish Flatcoated Retrievers. Applied Animal Behaviour Science 88, 289-298.

Lundberg, D.E. (1971) Why tourists travel. Cornell Hotel and Restaurant Administration Quarterly, 11(4), 75-81.

Mair, J., \& Thompson, K. (2009). The UK association conference attendance decision-making process. Tourism Management 30(3), 400-409.

Maslow, A. (1970). Motivation and personality. New York: Harper and Row.

Mayo, E.J., \& Jarvis L.P. (1981). The psychology of leisure travel: Effective marketing and selling of travel services. Boston: CBI Publishing Company.

Mohr, K., Backman, K.F., Gahan, L.W., \& Backman, S.J. (1993). An investigation of festival motivations and event satisfaction by visitor type. Festival Management and Event Tourism 1(3), 89-97.

Munuera, J.L., \& Ruiz, S. (1999). Trade fairs as services: a look at visitors' objectives in Spain. Journal of Business Research 44(1), 17-24.

Nicholson, R., \& Pearce, D.G. (2001). Why do people attend events: A comparative analysis of visitor motivations at four south island events. Journal of Travel Research, 39(4), 449-460.

O'Sullivan, D., Pickernell, D., \& Senyard, J.M. (2009). Public sector evaluation of festivals and special events. Journal of Policy Research in Tourism, Leisure and Events 1(1), 19-36.

Oppermann, M., \& Chon, K.S. (1997). Convention participation decisionmaking process, Annals of Tourism Research 24(1), 178-191 
Pasanen, K., Taskinen, H., \& Mikkonen, J. (2009). Impacts of cultural events in Eastern Finland - Development of a Finnish event evaluation tool. Scandinavian Journal of Hospitality and Tourism 9 (2-3), 112-129.

Pearce, P.L. (1982). The social psychology of tourist behavior. Oxford: Pergamon Press.

Rittichainuwat, B., \& Mair, J. (2012). Visitor attendance motivations at consumer travel exhibitions. Tourism Management 33, 1236-1244.

Rittichainuwat, B.N., Beck, J.A., \& LaLopa, J. (2001). Understanding motivations, inhibitors, and facilitators of association members in attending international conferences. Journal of Convention \& Exhibition Management, 3(3), 45-62.

Schofield, P., \& Thompson, K. (2007). Visitor motivation, satisfaction and behavioural intention: The 2005 Naadam Festival, Ulaanbaatar. International Journal of Tourism Research 9, 329-344.

Scott, D. (1996). A comparison of visitors' motivations to attend three urban festivals. Festival Management and Event Tourism 3(3), 121-128.

Severt, D., Wang, Y., Chen, P.-J., \& Breiter, D. (2007). Examining the motivation, perceived performance, and behavioral intentions of convention attendees: Evidence from a regional conference. Tourism Management 28, 399-408.

Smith, T.M., Hama, K., \& Smith, P.M. (2003). The effect of successful trade show attendance on future show interest: exploring Japanese attendee perspectives of domestic and offshore international events. Journal of Business and Industrial Marketing 18(4/5), 403-418.
Tanford, S., Montgomery, R., Nelson, K.B. (2012). Factors that influence attendance, satisfaction, and loyalty for conventions. Journal of Convention \& Event Tourism 13(4), 290-318.

Tanner, J.F., Chonko, L.B., \& Ponzurick, T.V. (2001) A learning model of trade exhibition attendance. Journal of Convention and Exhibition Management 3(3), 3-26.

Uysal, M., \& Hagan, L. (1993) Motivations of pleasure travel and tourism. In $\mathrm{M}$. Khan, M. Olsen, T.Var (Eds.), Encyclopaedia of hospitality and tourism (pp 798-810). New York: Van Nostrand Reinhold.

Uysal, M., \& Jurowski, C. (1994). Testing the push and pull factors. Annals of Tourism Research 21(4), 844-846.

Uysal, M., Gahan, L., Martin, B. (1993). An examination of event motivations: A case study. Festival Management and Event Tourism 1, 5-10.

Wallrabenstein, K. (2009). The importance of pull factors of tourist motivation for potential tourists in Vojvodina. Hotellink 13-14, 856-861, Proceedings of the international scientific and professional conferences HOTELPLAN 2009, Belgrade 2009.

Whitfield, J., \& Webber, D.J. (2011). Which exhibition attributes create repeat visitation? International Journal of Hospitality Management 30, 439-447.

Yoo, J.J.-E., \& Chon, K. (2008). Factors affecting convention participation decision-making: developing a measurement scale. Journal of Travel Research 47, 113-122. 